\title{
Підхід до аналізу ефективності використання встановленої холодопродуктивності систем кондиціювання припливного повітря
}

\author{
С. І. Труиляков, М. І. Радченко, С. А. Кантор, В. С. Ткаченко
}

Національний університет кораблебудування ім. адм. Макарова, проспект Героїв України 9, Миколаїв, 54002, Україна $\triangle$ e-mail: nirad50@gmail.com

\begin{abstract}
Запропоновано підхід до аналізу ефективності використання встановленої (проектної) холодопродуктивності холодильних машин систем кондиціювання припливного повітря (СКПП) з урахуванням змін теплових навантажень у відповідності з поточними кліматичними умовами. При цъьому порівнюють потенційно можливе вироблення холоду (виходячи з наявної встановленої холодопродуктивності) за певний період, як приклад - за найбільш теплий липень місяиь, з ї̈ використанням на попереднє охолодження зовнішнього повітря до певної проміжної (порогової) температури, і подальше глибоке охолодження повітря при відносно стабільному тепловому навантаженні. Висунуто гіпотезу попередньої оцінки доцільності застосування регулювання холодопродуктивності за співвідношенням сумарних за деякий проміжок часу використання холоду на охолодження зовнішнього повітря і потенційно можливого вироблення холоду при повній реалізації наявної встановленої холодопродуктивності СКПП. Запропонований підхід до вибору рачіональної встановленої холодопродуктивності СКПП та ї̈ розподілу відповідно до характеру зміни теплового навантаження у відповідності з поточними кліматичними умовами доцільно використовувати для визначення областей ефективного застосування енергозберігаючих способів реалізаџії холодопродуктивності, зокрема, акумуляиією та використанням надлишку холодопродуктивності при змінних теплових навантаженнях, частотного або іншого способу регулювання холодопродуктивності компресорів при відхиленнях теплового навантаження від номінального.
\end{abstract}

Ключові слова: Кондиціювання, Зовнішне повітря, Теплове навантаження, Холодильна машина, Клімат

(C) The Author(s) 2018. This article is an open access publication

This work is licensed under the Creative Commons Attribution 4.0 International License (CC BY) http://creativecommons.org/licenses/by/4.0/

\section{1. Аналіз проблеми і постановка мети дослі- дження}

Енерговитрати на тепловологісну обробку зовнішнього повітря в системах кондиціювання припливного повітря (СКПП) залежать від його тепловологісних параметрів (температури $t_{\text {нв }}$ та відносної вологості $\varphi_{\text {нв }}$ навколишнього повітря), які відрізняються значними змінами упродовж доби [1-3]. Основні положення методології вибору встановленої (проектної) холодопродуктивності холодильних машин (ХМ) СКПП в умовах нерівномірних теплових навантажень розглянуті в роботах [4-6].

Очевидно, що вироблення холоду за певний проміжок часу, наприклад рік (річна холодопродуктивність ХМ) $\sum\left(Q_{0} \cdot \tau\right)$, кВт·год, де $Q_{0}$ - поточна холодопродуктивність (теплове навантаження СКПП) ХМ, кВт; $\tau-$ тривалість роботи СКПП в годинах, характеризує використання встановлених холодильних потужностей ХМ СКПП $[7,8]$.

Оскільки кількість витраченого холоду на тепловологісну обробку припливного повітря в СКПП залежить від поточних температури $t_{\text {нв }}$ і відносної вологості $\varphi_{\text {нв}}$, глибини його охолодження, а також від тривалості $\tau$ роботи СКПП, то про ефективність використання встановленої (проектної) холодопродуктивності ХM СКПП можна робити висновки за співвідношення витраченого холоду за певний проміжок часу (при роботі ХM на змінних режимах теплового навантаження в залежності від поточних кліматичних умов) і потенційно можливого його вироблення при реалізації всієї встановленої холодопродуктивності (при роботі ХМ на повному, номінальному, навантаженні).

Мета дослідження - розробити підхід до аналізу ефективності використання встановленої (проектної) холодопродуктивності холодильних машин систем кондиціювання припливного повітря (СКПП) з урахуванням змін теплових навантажень у відповідності 3 поточними кліматичними умовами.

\section{2. Результати дослідження}

3 метою узагальнення результатів і перерахунку на інші холодильні потужності холодопродуктивність ХМ СКПП зручно представляти не в абсолютних, а у відносних (питомих) величинах, що припадають на одиничну витрату повітря $\left(G_{\mathrm{B}}=1 \kappa \Gamma / \mathrm{c}\right)-$ у вигляді питомого теплового навантаження, або холодопродуктивності, $q_{0}=Q_{0} / G_{\mathrm{B}}$, кВт/(кг/с), або кДж/кг, де $Q_{0}-$ повне теплове навантаження (холодопродуктивність) при охолодженні повітря витратою $G_{\mathrm{B}}: Q_{0}=\left(c_{\text {вл }} \xi \cdot \Delta t_{\mathrm{B}}\right) G_{\text {в }}$, $c_{\text {вл }}-$ теплоємність вологого повітря; $\xi$ - коефіцієнт вологовипадіння; $\Delta t_{\text {в }}-$ зниження температури повітря.

Для обгрунтування підходу до аналізу ефективності використання встановленої (проектної) холодопродуктивності холодильних машин СКПП з урахуванням зміни теплових навантажень у відповідності з поточними кліматичними умовами розглянуті поточні значення 
питомих теплових навантажень $q_{0}$ на ХМ СКПП при охолодженні зовнішнього повітря від поточної температури $t_{\text {нв }}$ до $t_{\mathrm{B} 2}=10,15 \mathrm{i} 20^{\circ} \mathrm{C}$, відповідно $q_{0.10}, q_{0.15} \mathrm{i}$ $q_{0.20}$ для найбільш теплого липня місяця $2017 \mathrm{p}$. (рис. 1).

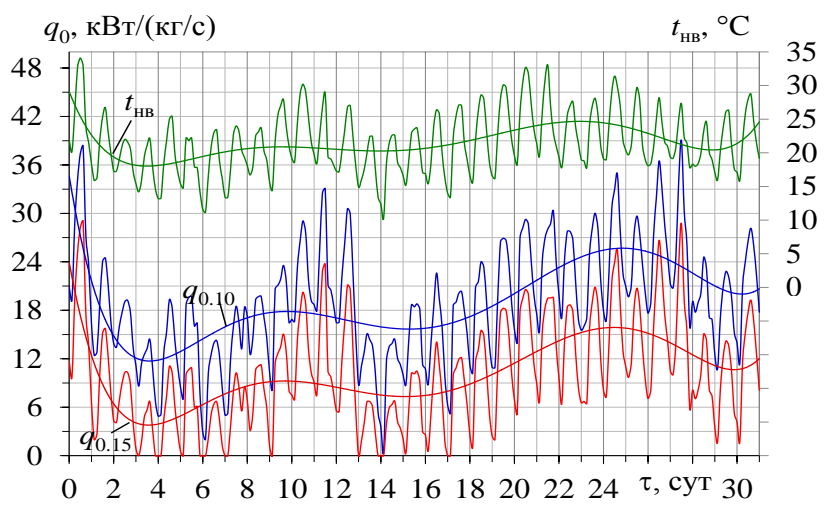

Рисунок 1 - Поточні значення температури зовнішнього повітря $t_{\text {нв}}$, питомих теплових навантажень $q_{0.10}$ i $q_{0.15}$ охолодження зовнішнього повітря від поточної температури $t_{н в}$ до $t_{62}=10$ i $15{ }^{\circ} \mathrm{C}$ для кліматичних умов м Вознесенськ, Миколаӥвська обл., 2017 р.

Як видно, при охолодженні зовнішнього повітря від поточних його температур $t_{\text {нв }}$ до $t_{\text {в2 }}=10 \mathrm{i} 15^{\circ} \mathrm{C}$ коливання теплових навантажень $q_{0.10}$ i $q_{0.15}$ вельми значні. Практично еквідистантні лінії тренда теплових навантажень $q_{0.10}$ і $q_{0.15}$ свідчать про те, що ці коливання обумовлені перш за все змінами теплових навантажень $q_{0.15}$ попереднього охолодження зовнішнього повітря до температури $t_{\mathrm{B} 2}=15^{\circ} \mathrm{C}$, в процесі якого відбувається практично демпфування коливань поточного навантаження.

У той же час при подальшому охолодженні повітря від проміжної температури $t_{\mathrm{B} 2}=15^{\circ} \mathrm{C}$ до $t_{\mathrm{B} 2}=10^{\circ} \mathrm{C}$ коливання теплового навантаження на СКПП $q_{0.10-15}=$ $=q_{0.10}-q_{0.15}$ порівняно невеликі: $9 \ldots 11 \mathrm{\kappa BT} /(\kappa г / \mathrm{c})$, не враховуючи 3-5 короткочасних сплесків-падінь величини $q_{0.10-15}$, обумовлених зниженням поточних значень температури зовнішнього повітря нижче $15^{\circ} \mathrm{C}$ (рис. 2).

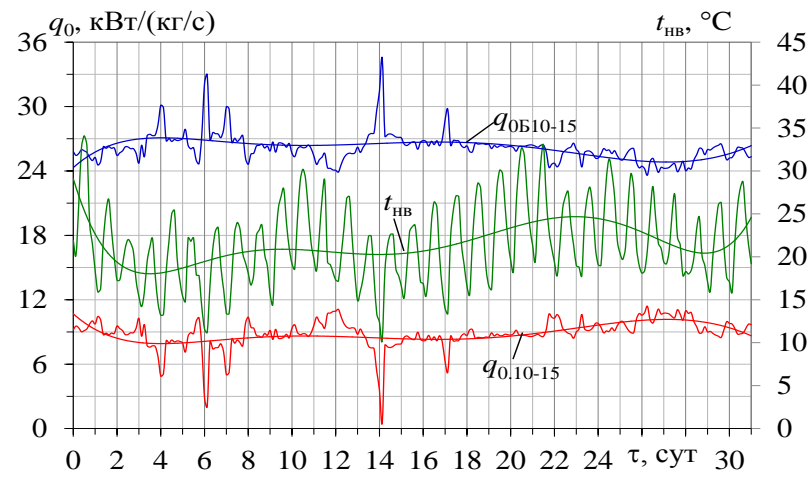

Рисунок 2 - Поточні значення температури зовнішнього повітря $t_{\text {нв }}$, питомого теплового навантаження $q_{0.10-15}=q_{0.10}-q_{0.15}$ глибокого охолодження повітря від температури $t_{62}=15^{\circ} \mathrm{C}$ до $t_{62}=10^{\circ} \mathrm{C}$, теплового навантаження $q_{0.510-15}=35-q_{0.10-15}$ попереднього охолодження зовнішнього повітря від $t_{н в}$ до $t_{62}=15^{\circ} \mathrm{C}$, розрахованої за остаточним принцииом
3 урахуванням відносно стабільного характеру питомого теплового навантаження на повітроохолоджувач (ПО) СКПП $q_{0.10-15}=q_{0.10}-q_{0.15}$ при охолодженні повітря від температури $t_{\mathrm{B} 2}=15^{\circ} \mathrm{C}$ до $t_{\mathrm{B} 2}=10^{\circ} \mathrm{C}$ в порівнянні 3 охолодженням зовнішнього повітря від $t_{\text {нв }}$ до $t_{\text {в2 }}=$ $=15{ }^{\circ} \mathrm{C}$ його приймають в якості проектного для глибокого охолодження повітря від $t_{\mathrm{B} 2}=15^{\circ} \mathrm{C}$ до $t_{\mathrm{B} 2}=10^{\circ} \mathrm{C}$. Відповідно, проектне теплове навантаження, що припадає на переднє охолодження зовнішнього повітря від поточної температури $t_{\mathrm{нв}}$ до $t_{\mathrm{B} 2}=15^{\circ} \mathrm{C}$, бустерну складову, визначають за залишковим принципом як різни-

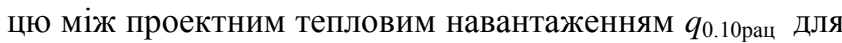
всього процесу охолодження зовнішнього повітря від поточної $t_{\text {нв }}$ до $t_{\mathrm{B} 2}=10{ }^{\circ} \mathrm{C}$ і його стабільної складової $q_{0.10-15}: q_{0.510-15}=q_{0.10 \text { рац }}-q_{0.10-15}$ (рис. 2 ).

При цьому за раціональне проектне теплове навантаження $q_{0.10 \text { рац }}$ для всього процесу охолодження зовнішнього повітря від поточного $t_{\text {нв }}$ до $t_{\mathrm{B} 2}=10^{\circ} \mathrm{C}$ приймають його величину $q_{0.10 \text { рац }}=35$ кВт/(кг/c), або кДж/кг, що забезпечує близьке до максимального річне вироблення холоду $\sum\left(q_{0} \cdot \tau\right) \approx 48$ кВт·год/(кг/с) (рис. 3$)$.

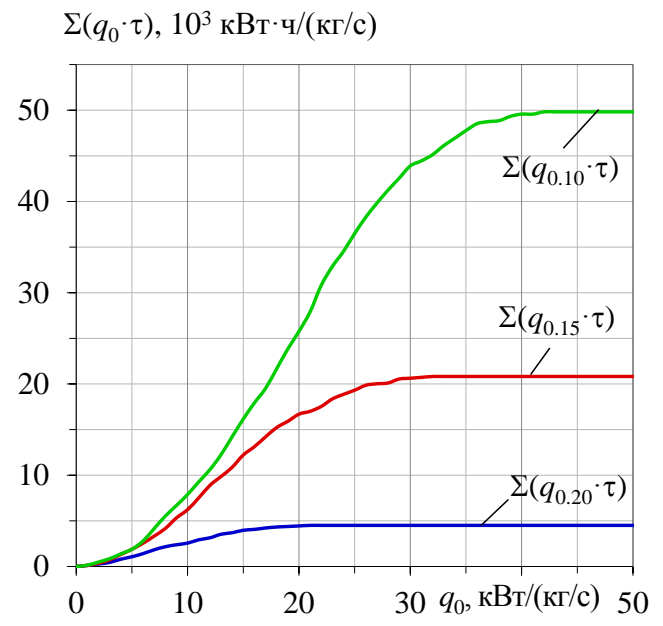

Рисунок 3 - Значення питомого річного виробництва холоду $\sum\left(q_{0} \cdot \tau\right)$ в залежності від питомої встановленої холодопродуктивності XM $q_{0}: \sum\left(q_{0} \cdot \tau\right)_{10 ; 15 ; 20}-$ при $t_{62}=$ 10; 15 i $20{ }^{\circ} \mathrm{C}$ для кліматичних умов м Вознесенськ, Миколаївська обл., 2017 p.

Як видно, для розглянутих кліматичних умов при охолодженні повітря до температури $t_{\mathrm{B} 2}=10^{\circ} \mathrm{C}$ в СКП 3 холодильною машиною встановленої питомої (при $G_{\mathrm{B}}=1$ кг/c) холодопродуктивності $q_{0}=35 \mathrm{\kappa BT} /(\kappa \Gamma / \mathrm{c})$ величина питомого виробництва холоду $\sum\left(q_{0} \cdot \tau\right)$ за 2017 р. складає 48 кВт·год/(кг/с), причому при збереженні високих темпів ії нарощування.

Аналогічно при охолодженні повітря до температури $t_{\mathrm{B} 2}=15^{\circ} \mathrm{C}$ за раціональну приймають питому холодопродуктивність ХМ $q_{0}=25 \mathrm{\kappa BT} /(\kappa г / \mathrm{c})$, а до $t_{\mathrm{B} 2}=$ $=20^{\circ} \mathrm{C}-$ величину $q_{0}=15 \mathrm{\kappa BT} /(\kappa г / \mathrm{c})$.

Оскільки коливання поточного теплового навантаження охолодження зовнішнього повітря від $t_{\text {нв }}$ до $t_{\mathrm{B} 2}=10^{\circ} \mathrm{C}$ припадають в основному на іiі частину $q_{0.15}$, що відповідає попередньому охолодженню зовнішнього повітря від $t_{\text {нв }}$ до $t_{\mathrm{B} 2}=15^{\circ} \mathrm{C}$, то при підвищених поточних теплових навантаженнях $q_{0.15}$ буде мати місце деякий дефіцит проектної бустерної складової $q_{0 . Б 10-15}=$ 
$=35-q_{0.10-15}$, розрахованої за залишковим принципом, а при знижених $q_{0.15}$, навпаки,- iї надлишок $q_{0 . \text { Бизб }}=$ $=35-q_{0.510-15}=35-q_{0.15}$ в порівнянні 3 поточним тепловим навантаженням $q_{0.15}$ (рис. 4 ).

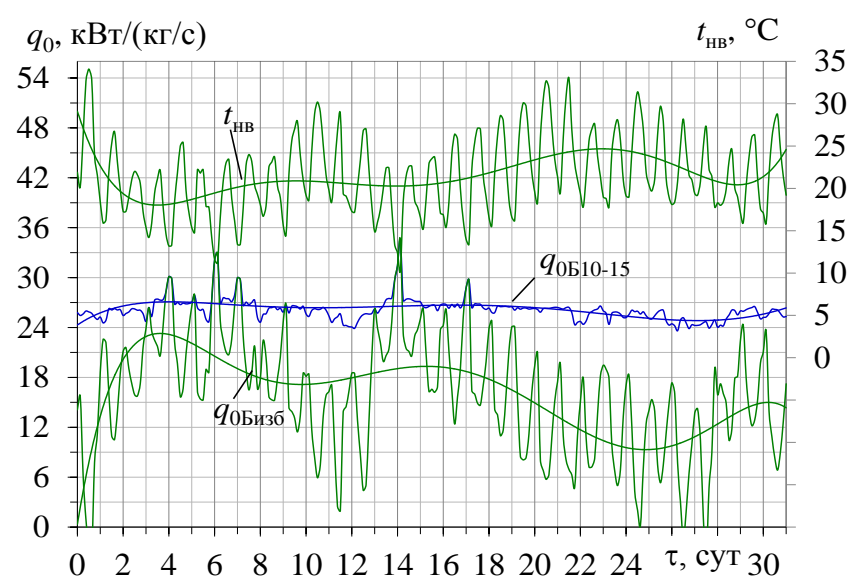

Рисунок 4 - Поточні значення температури зовнішнього повітря $t_{\text {нв }}$ питомої проектної бустерної складової теплового навантаження попереднього охолодження повітря $q_{0.510-15}=35-q_{0.10-15}$, розрахованої $з а$ залишковим принципом, і надлишку проектної бустерной складової q0.Бизб в порівнянні з поточним тепловим навантаженням $q_{0.15}$

Як видно 3 рис. 4, сплески (надлишок) поточних значень питомого теплового навантаження $q_{0.510-15}=$ $=35-q_{0.10-15}$ попереднього охолодження зовнішнього повітря від його поточної температури $t_{\text {нв }}$ до $t_{\mathrm{B} 2}=15^{\circ} \mathrm{C}$ понад iї проектну величину $q_{0.510-15}$ мають місце при падінні поточного питомого теплового навантаження $q_{0.15}$ до нуля, а те, що надлишок поточних значень питомого теплового навантаження $q_{0.510-15}$ в окремі дні (4, 6, 7, 14 і 17 липня 2017 р.) перевищує проектну величину $q_{0.510-15}$, пояснюється скороченням теплового навантаження $q_{0.10-15}$ глибокого доохолодження повітря при зниженні поточної температури зовнішнього повітря $t_{\text {нв }}$ нижче $15^{\circ} \mathrm{C}$.

Про те, наскільки ефективно (повно) витрачається встановлена (проектна) бустерна складова холодопродуктивності СКПП на попереднє охолодження зовнішнього повітря від його поточної температури $t_{\text {нв }}$ до $t_{\mathrm{B} 2}=15^{\circ} \mathrm{C}$ при зміні теплових навантажень відповідно до поточних кліматичних умов можна судити по співвідношенню сумарних по накопиченню за місяць питомих величин витрачання холодопродуктивності на покриття поточних теплових навантажень $\sum\left(\mathrm{q}_{0.15} \cdot \tau\right)$ охолодження зовнішнього повітря від поточної температури $\mathrm{t}_{\text {нв }}$ до $\mathrm{t}_{\mathrm{B} 2}=15^{\circ} \mathrm{C}$, потенційно можливого вироблення холоду бустерним ступенем попереднього охолодження зовнішнього повітря відповідно до його проектної питомої холодопродуктивності, розрахованої за залишковим принципом, $\sum\left(\mathrm{q}_{0.510-15} \cdot \tau\right)$, а також потенційно можливого надлишку вироблення холоду бустер-

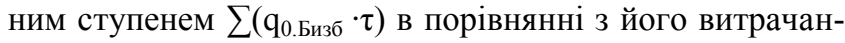
ням $\sum\left(\mathrm{q}_{0.15} \cdot \tau\right)$ на охолодження зовнішнього повітря до $\mathrm{t}_{\mathrm{B} 2}=15^{\circ} \mathrm{C}$ на рис. 5. Там же нанесені сумарні по накопиченню за місяць питомі величини витрачання холодопродуктивності $\sum\left(q_{0.10-15} \cdot\right)$ на глибоке доохолодження повітря від $\mathrm{t}_{\mathrm{B} 2}=15^{\circ} \mathrm{C}$ до $\mathrm{t}_{\mathrm{B} 2}=10^{\circ} \mathrm{C}$.

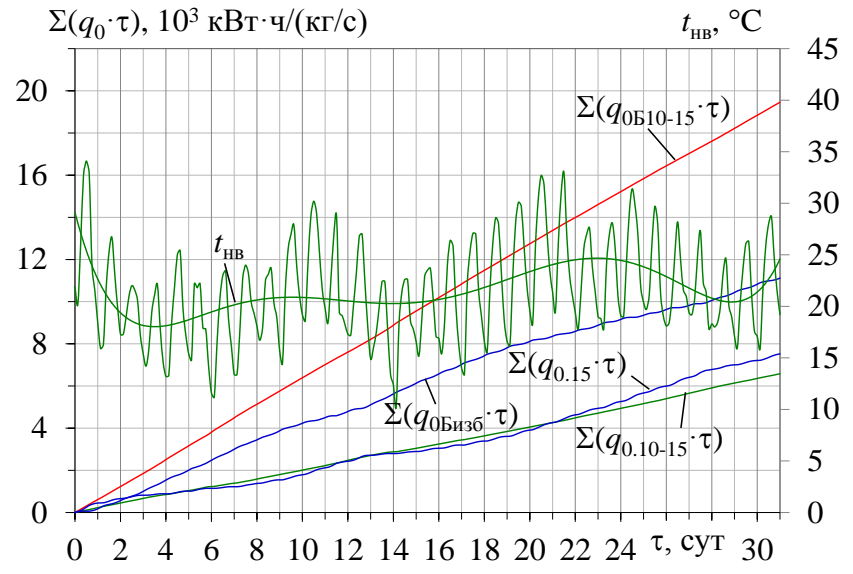

Рисунок 5 - Поточні значення температури зовнішнього повітря $t_{н 6}$, сумарних по накопиченню за місяць питомих величин витрачання холодопродуктивності $\sum\left(q_{0.15} \cdot \tau\right)$ на охолодження зовнішнього повітря до $t_{62}=15^{\circ} \mathrm{C}$, потенційно можливого вироблення холоду бустерним ступенем попереднього охолодження зовнішнього повітря відповідно до його проектної величини, $\sum\left(q_{0 . Б 10-15} \tau\right)$, а також потенційно можливого надлишку вироблення холоду бустерним ступенем

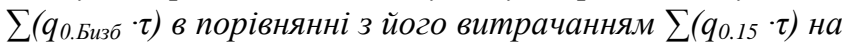
охолодження зовнішнього повітря до $t_{62}=15^{\circ} \mathrm{C}$, а також величини витрачання холодопродуктивності $\sum\left(q_{0.10-15} \cdot\right)$ на глибоке доохолодження повітря від $t_{62}=15^{\circ} \mathrm{C}$ до $t_{62}=10^{\circ} \mathrm{C}$

Як видно, сумарне за місяць витрачання питомої холодопродуктивності $\sum\left(\mathrm{q}_{0.15} \cdot \tau\right)$ на охолодження зовнішнього повітря до $\mathrm{t}_{\mathrm{B} 2}=15^{\circ} \mathrm{C}$ складає $\sum\left(\mathrm{q}_{0.15} \cdot \tau\right) \approx$ $\approx 7$ кВт·год/(кг/с), або кДж/(кг/ч), що менше надлишку потенційно можливого вироблення холоду бустерним ступенем попереднього охолодження зовнішнього пові-

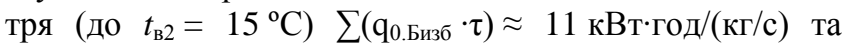
складає менше $40 \%$ потенційно можливого вироблення холоду бустерним ступенем $\sum\left(\mathrm{q}_{0.510-15} \cdot \tau\right) \approx$ $\approx 19$ кВт.год/(кг/с).

У першому наближенні можна припустити, що сумарне за місяць витрачання питомої холодопродуктивності $\sum\left(\mathrm{q}_{0.15} \cdot \tau\right) \approx 7$ кВт·год/(кг/с), що складає $40 \%$ потенційно можливого вироблення холоду бустерним ступенем $\sum\left(\mathrm{q}_{0.510-15} \cdot \tau\right) \approx 19$ кВт.год/(кг/с), відповідає необхідному діапазону регулювання холодопродуктивності від $100 \%$ до 40 \% номінальної. Виходячи 3 цієї гіпотези, застосування холодильних компресорів з частотним регулюванням холодопродуктивності до $40 \%$ можна було б розглядати як спосіб енергетично ефективної роботи СКПП попереднього охолодження зовнішнього повітря до $\mathrm{t}_{\mathrm{B} 2}=15^{\circ} \mathrm{C}$.

Однак, з урахуванням того, що надлишок холодопродуктивності $\sum\left(\mathrm{q}_{0.510-15} \tau\right)$ в більш прохолодні періоди буде ще більший, ефективність застосування холодильних компресорів з частотним регулюванням холодопродуктивності в системах кондиціювання зовнішнього повітря в області його попереднього охолодження є маловірогідною.

Очевидно, що чим вище граничне значення температури попереднього охолодження зовнішнього пові- 
тря (проміжної температури $t_{\text {в2 }}$ ), тобто більш вузький діапазон коливань теплових навантажень, тим довше тривалість експлуатації холодильної машини бустерного ступеня попереднього охолодження повітря упродовж року при теплових навантаженнях (холодопродуктивності), близьких до номінальних.

3 метою визначення верхнього порогового значення температури попереднього охолодження зовнішнього повітря були виконані розрахунки процесів охо-

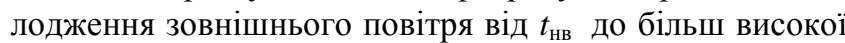
проміжної температури $t_{\mathrm{B} 2}=20^{\circ} \mathrm{C}$ і відповідних теплових навантажень на подальше доохолодження повітря $q_{0.10-20}=q_{0.10}-q_{0.20}$ от $t_{\mathrm{B} 2}=20^{\circ} \mathrm{C}$ до $t_{\mathrm{B} 2}=10^{\circ} \mathrm{C}$ (рис. 6).

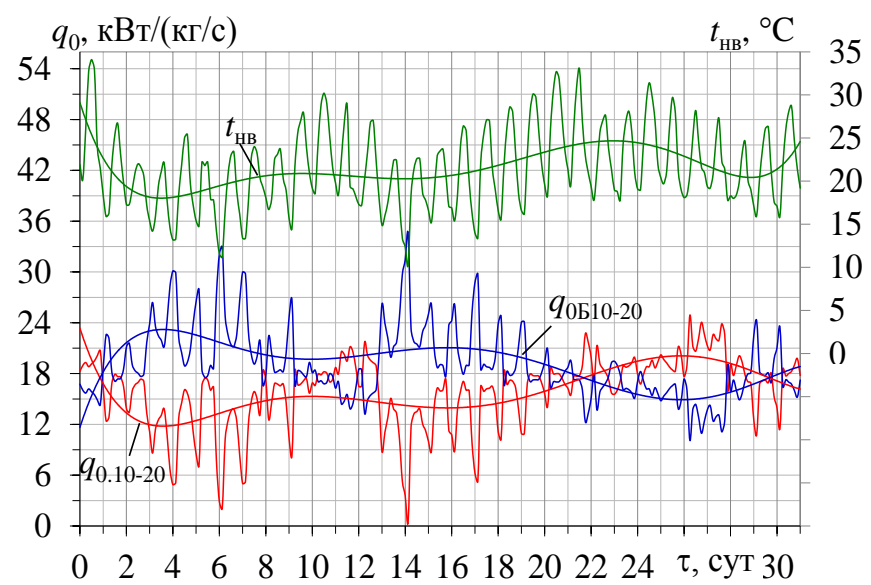

Рисунок 6 - Поточні значення температури зовнішнього повітря $t_{н в}$, питомого теплового навантаження $q_{0.10-20}=q_{0.10}-q_{0.20}$ глибокого охолодження повітря від температури $t_{62}=20{ }^{\circ} \mathrm{C}$ до $t_{62}=10^{\circ} \mathrm{C}$, теплового навантаження $q_{0 . Б 10-20}=34-q_{0.10-20}$ попереднього охолодження зовнішнього повітря від $t_{н в}$ до $t_{62}=20^{\circ} \mathrm{C}$, розрахованого за залишковим принципом

Як видно 3 рис. 6 , теплове навантаження $q_{0.10-20}=$ $=q_{0.10}-q_{0.20}$ на доохолодження повітря від проміжної температури $t_{\mathrm{B} 2}=20^{\circ} \mathrm{C}$ до кінцевої $t_{\mathrm{B} 2}=10^{\circ} \mathrm{C}$ стає вельми нестабільним у порівнянні з більш низькою проміжною температурою $t_{\mathrm{B} 2}=15^{\circ} \mathrm{C}$ (рис. 2). Це викликано більш раннім (при $t_{\mathrm{B} 2}=20^{\circ} \mathrm{C}$ ) падінням до нуля теплового навантаження $q_{0.20}$ попереднього охолодження зовнішнього повітря, обумовленим звуженням діапазону температур $\Delta t_{20}=t_{\text {нв }}-20^{\circ} \mathrm{C}$ охолодження зовнішнього повітря при підвищеній проміжній температурі $t_{\mathrm{B} 2}=20^{\circ} \mathrm{C}$ (у порівнянні $3 \Delta t_{15}=t_{\text {нв }}-15^{\circ} \mathrm{C}$ при $t_{\mathrm{B} 2}=$ $\left.=15^{\circ} \mathrm{C}\right)$, наслідком чого $\epsilon$ перенесення коливань теплового навантаження, раніше демпфованого при охолодженні зовнішнього повітря до температури $t_{\mathrm{B} 2}=15^{\circ} \mathrm{C}$, i відповідне збільшення теплового навантаження $q_{0.10-20}=q_{0.10}-q_{0.20}$ подальшого доохолодження у повітря від температури $t_{\mathrm{B} 2}=20{ }^{\circ} \mathrm{C}$ до $t_{\mathrm{B} 2}=10^{\circ} \mathrm{C}$.

Про те, що при підвищеній проміжної температурі $t_{\mathrm{B} 2}=20^{\circ} \mathrm{C}$ охолодження зовнішнього повітря встановлена (проектна) бустерна складова холодопродуктивності СКПП на попереднє охолодження зовнішнього повітря витрачається менш ефективно, і більш того, утворюється надлишок холодопродуктивності $q_{0.10-20}=$ $=q_{0.10}-q_{0.20}$ при доохолодженні повітря від температури $t_{\mathrm{B} 2}=20^{\circ} \mathrm{C}$ до $t_{\mathrm{B} 2}=10^{\circ} \mathrm{C}$, можна судити по співвідно- шенню сумарних по накопиченню за місяць питомих величин наявної холодопродуктивності і її витрачання на покриття поточних теплових навантажень на рис. 7.

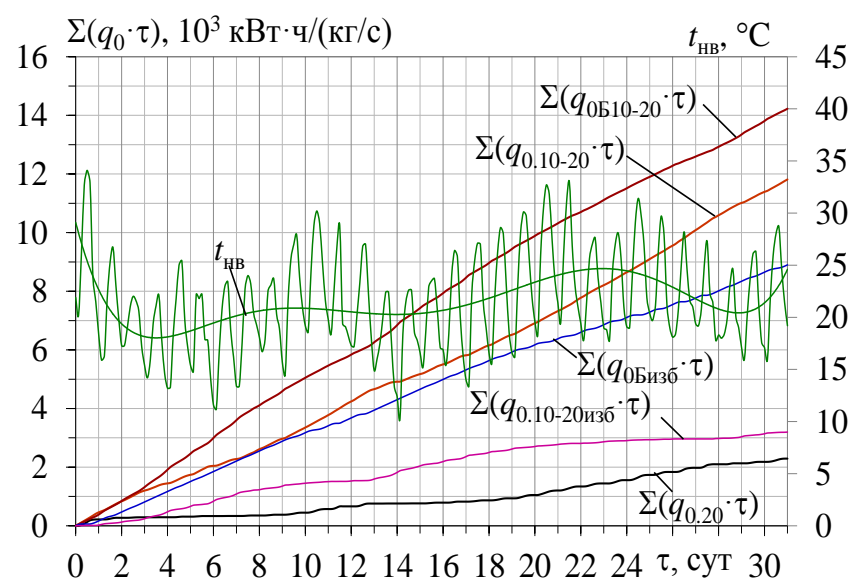

Рисунок 7 - Поточні значення температури зовнішнього повітря $t_{\text {нв }}$ сумарних по накопиченню за місяцьь питомих величин витрачання холодопродуктивності $\sum\left(q_{0.20} \cdot \tau\right)$ на охолодження зовнішнього повітря до $t_{62}=$ $20{ }^{\circ} \mathrm{C}$, потениійно можливого вироблення холоду бустерним ступенем попереднього охолодження зовнішнього повітря відповідно до його проектної величиною, $\sum\left(q_{0 . Б 10-20} \cdot \tau\right)$, а також потенційно можливого надлишку вироблення холоду бустерним ступенем $\sum\left(q_{0 . \text { Биз }} \cdot \tau\right)$ в порівнянні з його витрачанням $\sum\left(q_{0.20} \cdot \tau\right)$ на охолодження зовнішнього повітря до $t_{62}=20{ }^{\circ} \mathrm{C}$, а також витрачання холодопродуктивності $\sum\left(q_{0.10-20} \tau\right)$ на доохолодження повітря від $t_{62}=20{ }^{\circ} \mathrm{C}$ до $t_{62}=10{ }^{\circ} \mathrm{C} i$ надлишку проектної холодопродуктивності $\sum\left(q_{0.10-}\right.$ $20 и з б \cdot \tau)$ в порівнянні з ї̈ витратою

Порівняння питомих теплових навантажень глибокого охолодження повітря $q_{0.10-15}=q_{0.10}-q_{0.15}$ i $q_{0.10-20}=q_{0.10}-q_{0.20}$ показує, що стабілізація теплового навантаження відбувається в результаті попереднього охолодження зовнішнього повітря до нижчої пропроміжної температури $t_{\mathrm{B} 2}=15^{\circ} \mathrm{C}$ у порівнянні 3 $t_{\mathrm{B} 2}=20^{\circ} \mathrm{C}$. Отже, теплове навантаження $q_{0.10-15}=q_{0.10}$ $q_{0.15}$ приймають в якості базового, що забезпечує ефективну роботу ХМ в режимі, близькому номінальному, $\mathrm{i}$ виходячи 3 нього розраховують теплове навантаження попереднього охолодження повітря $q_{0.510-15}$ до температури $t_{\mathrm{B} 2}=15^{\circ} \mathrm{C}$ за залишковим принципом як $q_{0 . Б 10-15}=$ $=q_{0.10 \mathrm{paц}}-q_{0.10-15}$.

Як видно, сумарне за місяць витрачання питомої холодопродуктивності $\sum\left(\mathrm{q}_{0.20} \cdot \tau\right)$ на охолодження зовнішнього повітря до $\mathrm{t}_{\mathrm{B} 2}=20^{\circ} \mathrm{C}$ складає $\sum\left(\mathrm{q}_{0.20} \cdot \tau\right) \approx$ $\approx 2$ кВт·год/(кг/с), або кДж/(кг/год), що набагато менше надлишку потенційно можливого вироблення холоду бустерним ступенем попереднього охолодження зовнішнього повітря (до $\left.t_{\mathrm{B} 2}=20^{\circ} \mathrm{C}\right) \quad \sum\left(\mathrm{q}_{\text {0.Бизб }} \cdot \tau\right) \approx$ $\approx 9$ кВт.год/(кг/с) і становить менше $15 \%$ потенційно можливого вироблення холоду бустерним ступенем $\sum\left(\mathrm{q}_{0.510-20} \cdot \tau\right) \approx 14$ кВт·год/(кг/с). Недостатне демпфування падіння поточного теплового навантаження у процесі попереднього охолодження зовнішнього повітря до $\mathrm{t}_{\mathrm{B} 2}=20^{\circ} \mathrm{C}$ (у порівнянні $3 \mathrm{t}_{\mathrm{B} 2}=15^{\circ} \mathrm{C}$ ) призводить до утворення надлишку проектної холодопродуктивності 


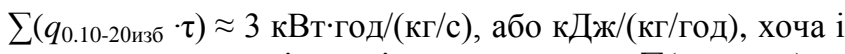
незначного у порівнянні 3 ії витратою $\sum\left(\mathrm{q}_{0.10-20} \cdot \tau\right) \approx$ $\approx 12$ кВт.год/(кг/с) при подальшому доохолодженні повітря від температури $t_{\mathrm{B} 2}=20^{\circ} \mathrm{C}$ до $t_{\mathrm{B} 2}=10^{\circ} \mathrm{C}$. Очевидно, що застосування холодильних компресорів 3 частотним регулюванням холодопродуктивності може виявитися ефективним в області теплових навантажень $q_{0.10-20}$ доохолодження повітря до $\mathrm{t}_{\mathrm{B} 2}=10^{\circ} \mathrm{C}$, тоді як демпфування бустерних теплових навантажень $q_{0.510-20}$ попереднього охолодження зовнішнього повітря до $\mathrm{t}_{\mathrm{B} 2}=$ $=20^{\circ} \mathrm{C}$ їх застосування можливе тільки спільно 3 акумуляцією надлишкового холоду.

Таким чином, запропонований підхід до аналізу ефективності використання встановленої (проектної) холодопродуктивності СКПП може бути застосований як для вибору iї раціонального розподілу в залежності від характеру зміни теплового навантаження, так і 3 метою визначення діапазонів теплових навантажень для ефективного застосування різних способів регулювання холодопродуктивності СКПП.

\section{Висновки}

Запропоновано підхід до аналізу ефективності реалізації встановленої (проектної) холодопродуктивності систем кондиціювання припливного повітря (СКПП) 3 урахуванням зміни теплових навантажень у відповідності 3 поточними кліматичними умовами. При цьому порівнюють потенційно можливе вироблення холоду (виходячи 3 наявної встановленої холодопродуктивності) за певний період, як приклад - за найбільш теплий липень місяць, з ії витрачанням на попереднє охолодження зовнішнього повітря до певної проміжної (порогової) температури, і подальше глибоке охолодження повітря при відносно стабільному тепловому навантаженні.

Висунуто гіпотезу попередньої оцінки доцільності застосування холодильних компресорів 3 частотним регулюванням холодопродуктивності по співвідношенню сумарних за деякий проміжок часу витрачання холодопродуктивності на попереднє охолодження зовнішнього повітря до деякої проміжної (порогової) температури і потенційно можливого вироблення холоду при повній реалізації наявної встановленої холодопродуктивності СКПП.

Запропонований метод вибору раціональної встановленої (проектної) холодопродуктивності систем кондиціювання припливного повітря (СКПП) і їі розподілу відповідно до характеру зміни теплового навантаження у відповідності з поточними кліматичними умовами доцільно застосовувати для визначення областей ефективного застосування енергозберігаючих методів використання холодопродуктивності, зокрема, акумуляцією надлишку холодопродуктивності та іiі реалізаці- єю при змінних теплових навантаженнях кондиціювання зовнішнього повітря і частотного чи іншого способу регулювання холодопродуктивності в діапазоні незначних відхилень теплового навантаження від номінального.

\section{Література}

1. Marque, R.P. Thermodynamic analysis of trigeneration systems taking into account refrigeration, heating and electricity load demands [Text] / R.P. Marques, D. Hacon, A. Tessarollo, J.A.R. Parise. Energy and Buildings, 2010, vol. 42, pp. 2323-2330.

2. Ortiga, J., Operational optimisation of a complex trigeneration system connected to a district heating and cooling network [Text] / Ortiga Jordi, Bruno Joan Carles, Coronas Alberto, Applied Thermal Engineering, 2013, vol. 50, pp. 1536-1542.

3. Трушляков Е. И. Методологический подход к энергосберегающему хладоснабжению систем кондиционирования воздуха адаптацией к текущим климатическим условиям.// Авиационно-космическая техника и технология. - 2018. - № 4(148). - С. 58-62.

4. Trushliakov E., Radchenko M., Kantor S. Methodological approach to improve the efficiency of air conditioning system performance in changeable climatic conditions // Proceedings of the X Minsk International Seminar "Heat Pipes, Heat Pumps, Refrigerators, Power Sources", Minsk, Belarus, 10-13 September, 2018, pp. 444-450.

5. Trushliakov E., Radchenko M., Radchenko A., Kantor S., Zongming Y. Statistical approach to improve the efficiency of air conditioning system performance in changeable climatic conditions" The 5th "International Conference on Systems and Informatics: ICSAI 2018", Jiangsu, Nanjing, China, pp.1303-1307.

6. Radchenko A., Radchenko M., Trushliakov E., Kantor S., Tkachenko V. Statistical method to define rational heat loads on railway air conditioning system for changeable climatic conditions The $5^{\text {th }}$ "International Conference on Systems and Informatics: ICSAI 2018", Jiangsu, Nanjing, China, pp. 1308-1312.

7. Трушляков Е. И., Радченко Н. И., Ткаченко В. С. Подход к анализу эффективности регулирования холодопроизводительности систем кондиционирования приточного воздуха // Авиационно-космическая техника и технология. - 2018. - № 6(150). - С. 29-33.

8. Трушляков Е.И., Радченко Н.И., Зубарев А.А., Ткаченко В.С. Подход к определению составляющих тепловой нагрузки систем кондиционирования приточного воздуха.// Холодильна техніка та технологія. 2018. - Том 54, вип. 5. - С. 17-22.

\footnotetext{
Отримана в редакції 02.10.2018, прийнята до друку 04.12.2018
} 


\title{
Approach to analyzing the efficiency of using a design refrigeration capacity of ambient air conditioning system
}

\author{
E. I. Trushliakov, M. I. Radchenko, S. A. Kantor, V. S. Tkachenko \\ Admiral Makarov National University of Shipbuilding, Mykolaiv, Ukraine
}

\begin{abstract}
An approach to analyzing the efficiency of using an installed (design) refrigeration capacity of refrigeration machine of ambient air conditioning system (AACS) with taking into account the current climatic conditions of operation. With this a potential refrigeration capacity generation (according to available installed refrigeration capacity) during a definite time, as an example - during the most hot July month, with their spending for ambient air precooling down to a definite intermediate (threshold) temperature and further deep cooling the air at relatively stable heat load. The hypothesis of previous evaluation of the expedient application of refrigeration compressors with controlling the refrigeration capacity by using a frequency converter according to relation between the refrigeration capacity spending for ambient air precooling down to a definite intermediate (threshold) temperature and a potential refrigeration capacity generation with full realization of available installed refrigeration capacity of AACS summarized during a definite time. A proposed method for choosing a rational installed (design) refrigeration capacity of AACS and their shearing according to the behavior of heat load changing due to current climatic conditions of operation is quite expedient for determining the ranges of efficient application of energy saving methods of spending the available refrigeration capacity as an example by accumulation of excessive (unused) refrigeration capacity at lowered current heat loads on AACS and its using for ambient air precooling or by using a frequency converter for electric motor of refrigeration compressor for controlling the refrigeration capacity within small fluctuation of heat loads of deep subcooling the air precooled.
\end{abstract}

Keywords: conditioning, ambient air, heat load, refrigeration machine, climatic conditions.

\section{References}

1. Marques, R. P., Hacon, D., Tessarollo, A., Parise, J.A.R. (2010) Thermodynamic analysis of trigeneration systems taking into account refrigeration, heating and electricity load demands. Energy and Buildings, 42, 2323-2330.

2. Ortiga, J., Bruno, J. C., Coronas, A. (2013). Operational optimisation of a complex trigeneration system connected to a district heating and cooling network. Applied Thermal Engineering, 50, 1536-1542.

3. Trushliakov E.I. (2018) Methodological approach to energy saving cold supply of air conditioning system by matching current climatic conditions. Aerospace technics and technology, 4(148), 58-62.

4. Trushliakov E., Radchenko M., Kantor S. (2018) Methodological approach to improve the efficiency of air conditioning system performance in changeable climatic conditions. Proc. of the X Minsk International Seminar "Heat Pipes, Heat Pumps, Refrigerators, Power Sources", Minsk, Belarus, 10-13 September, 2018, pp. 444-450.

5. Trushliakov E., Radchenko M., Radchenko A., Kantor S., Zongming Y. (2018) Statistical approach to improve the efficiency of air conditioning system performance in changeable climatic conditions. The 5th International Conference on Systems and Informatics: ICSAI 2018, Jiangsu, Nanjing, China, pp.1303-1307.

6. Radchenko A., Radchenko M., Trushliakov E., Kantor S., Tkachenko V. (2018) Statistical method to define rational heat loads on railway air conditioning system for changeable climatic conditions The $5^{\text {th }}$ "International Conference on Systems and Informatics: ICSAI 2018", Jiangsu, Nanjing, China, pp. 1308-1312.

7. Trushliakov, E.I., Radchenko, N.I., Tkachenko, V.S. (2018) Approach to analyzing the efficiency of cooling capacity control of ambient air conditioning systems. Aerospace technics and technology, 6(150), pp. 29-33.

8. Trushliakov, E.I., Radchenko, N.I., Tkachenko, V.S. (2018) Approach to determine the components of ambient air conditioning system heat load. Refrigeration technics and technology, 54(5), 17-22. 